\title{
ПРАВОЗАХИСНА ДІЯЛЬНІСТЬ СЛІДЧОГО
}

\section{ВОВЧУК Любомир Святославович - здобувач Інституту права та суспільних відносин Відкритого міжнародного університету розвитку людини «Україна» \\ DOI:10.32782/NP.2019.4.27}

\begin{abstract}
В статті розкриваються сутність правозахисної діяльності слідчого під час проведення ним досудового розслідування кримінальних правопорушень та процесуальні форми іи реалізаиіï.

Ключові слова: кримінальне провадження, досудове розслідування, слідчий, правозахисна діяльність, учасники досудового розслідування, права людини.
\end{abstract}

Під час проведення досудового розслідування кримінальних правопорушень активно використовується увесь арсенал заходів забезпечення кримінального провадження, визначених главою 10 діючого КПК України, які носять державно-примусовий характер. Тож саме в цій стадії процесу проблема забезпечення прав, свобод і законних інтересів іiі учасників $\epsilon$ надзвичайно актуальною. Не випадково в означеній стадії діє найчисельніша група владних суб'єктів, порівняно з іншими стадіями кримінального провадження, які наділені правозахисними (правозабезпечувальними) повноваженнями публічного характеру. При цьому правозахисна діяльність реалізується владними суб'єктами досудового розслідування постійно і спрямована на недопущення порушень прав, свобод і законних інтересів учасників кримінального провадження [1, с. 19]. Цей вид діяльності владних суб'єктів досудового розслідування несе в собі як превентивний (попереджувальний), так і відновлювальний характер.
Як повноважний представник державного органу виконавчої влади, розслідуючи кримінальне правопорушення, слідчий, в силу категоричних вимог ст. 3 Конституції України і ст. 2 КПК України, зобов'язаний поряд з виконанням слідчих (розшукових) дій, негласних слідчих (розшукових) дій, інших процесуальних дій та прийняттям процесуальних рішень (початкових, проміжних, кінечних), у невідкладному порядку виконувати ще й правозахисну (правозабезпечувальну) функцію, пов'язану із забезпеченням прав, свобод і законних інтересів усіх фізичних осіб, залучених чи допущених до кримінальної процесуальної діяльності. Разом з тим, сутність і зміст означеної функції слідчого до цих пір продовжують залишатися чітко не визначеними ні на законодавчому, ні на теоретичному рівнях. Деякі автори обмежують правозахисну (правозабезпечувальну) діяльність слідчого лише створенням учасникам досудового розслідування належних умов для успішної реалізації ними своїх правомочностей [2, с. 27-28]. Це явне звуження правозахисної діяльності слідчого. Дійсно, слідчий зобов'язаний перед початком будь-якої процесуальної дії чітко і під розпис роз' яснити її учасникам їхні процесуальні права і обов'язки та створити безперешкодні умови для їх реалізації (ч. 3 ст. 223 КПК України). Проте роз'яснення прав і створення належних умов для їх реалізації це лише один із аспектів правоза- 
хисної (правозабезпечувальної) діяльності слідчого.

Правозахисний характер мають також i дії слідчого, пов’язані з наданням підозрюваному, обвинуваченому допомоги у встановленні зв'язку з обраним ним захисником-адвокатом чи особами, які можуть запросити захисника. Якщо за відсутністю коштів чи 3 інших об'єктивних причин підозрюваний, обвинувачений не може залучити захисника, а бажає його мати, то слідчий зобов'язаний залучити захисника для його захисту за призначенням - через орган (установу), уповноважений законом на надання безоплатної правової допомоги (ст. 49 КПК України). Слідчий також зобов’язаний забезпечити участь захисника і у випадках, коли його участь у кримінальному провадженні є обов'язковою (ст. 52 КПК України), надати йому реальну можливість на участь в розслідуванні до першого допиту підозрюваного (п. 3 ч. 3 ст. 42 КПК України) тощо.

Крім того, з метою забезпечення прав, свобод і законних інтересів підозрюваного, обвинуваченого слідчий під час проведення досудового розслідування кримінального правопорушення виявляє, фіксує, перевіряє, накопичує не тільки обвинувальні, а й виправдовувальні докази, 3'ясовує як обтяжуючі, так і пом'якшуючі обставини вчиненого правопорушення, вживає заходів до забезпечення як процесуальних, так і особистих та майнових прав цього учасника досудового розслідування (ч. 2 ст. 9 КПК України). Керуючись презумпцією невинуватості, усі сумніви щодо доведеності вини підозрюваного, обвинуваченого слідчий завжди тлумачить на користь підозрюваного, обвинуваченого, що є теж надійним правозахисним засобом [3, с. 84].

В разі крайньої необхідності слідчий приймає заходи, пов'язані з обмеженням прав підозрюваного, обвинуваченого, але це він робить вимушено і лише в тій мірі, в якій це необхідно для забезпечення прав, свобод і законних інтересів інших учасників досудового розслідування та створення умов для успішної реалізації кримінального судочинства. Такі дії слідчого теж но- сять правозахисний характер. Забезпечуючи підозрюваному, обвинуваченому всіх передбачених законом можливостей для захисту ним своїх прав, слідчий не перетворюється в його захисника, позаяк його публічна правозахисна (правозабезпечувальна) функція суттево відрізняється від приватної захисної функції підозрюваного, обвинуваченого, його законного представника і захисника-адвоката як за своїм змістом, так і направленістю та процесуальним порядком реалізації [4, с. 205-207].

Як повноважний представник державного органу виконавчої влади, слідчий у стадії досудового розслідування прикладає багато зусиль не тільки до забезпечення прав, свобод і законних інтересів підозрюваного, обвинуваченого, а й для забезпечення прав, свобод і законних інтересів законослухняної, базової для держави частини суспільства, яка потрапляє в орбіту кримінального провадження у зв'язку 3 заподіянням їй кримінальним правопорушенням фізичної, моральної, майнової чи іншої шкоди, визначеної конкретною нормою закону про кримінальну відповідальність. Попрані права, свободи і законні інтереси цих осіб не цікавлять учасників сторони захисту і забезпечення їхніх порушених прав - прямий обов'язок держави в особі таких їі владних суб'єктів досудового розслідування, як слідчий, прокурор i слідчий суддя.

Це значний обсяг правозахисної (правозабезпечувальної) діяльності означених владних суб'єктів досудового розслідування. Ведучим правозахисним засобом тут, звичайно, є розкриття слідчим вчиненого кримінального правопорушення [5, с. 125-128]. Проте законодавець України цього чомусь не враховує і не відображає у своїх нормативних актах. Навіть при прийнятті нового КПК України 2012 року він не відобразив означене положення в жодній статті цього закону, чим наніс суттевого ураження як правозахисній (правозабезпечувальній) діяльності слідчого, так і усьому кримінальному провадженню в цілому. Представляється, що це суттєве упущення законодавця повинно бути виправлене у невідкладному порядку. Не тільки 


\section{Дискусії, обговорення, актуально}

швидким і повним розкриттям кримінального правопорушення, а ще й всебічним, повним i неупередженим дослідженням усіх обставин його вчинення, слідчий закладає основу для забезпечення прав, свобод і законних інтересів осіб, постраждалих від кримінального правопорушення - потерпілого, цивільного позивача, їх законних представників та представників, іншими владними суб'єктами, діючими як у стадії досудового розслідування, так і в усіх послідуючих стадіях кримінального провадження [6, с. 229-231].

Під час проведення досудового розслідування кримінального правопорушення слідчий також встановлює характер і розмір завданої потерпілому і цивільному позивачу шкоди і приймає передбачені законом заходи по своєчасному і повному іiї відшкодуванню. Цю правозахисну дію слідчий розпочинає 3 роз'яснення підозрюваному, обвинуваченому чи фізичній або юридичній особі, яка в силу закону зобов'язана відшкодувати завдану потерпілому і цивільному позивачу кримінальним правопорушенням шкоду, про механізм її відшкодування у добровільному порядку (ч.1 ст. 127 КПК України). Якщо відшкодувати завдану шкоду у цьому порядку не вдалося, то слідчий з метою забезпечення цивільного позову приймає передбачені законом заходи до накладення арешту на майно вищеозначених осіб в порядку, встановленому ст. 170 КПК України. Цей правозахисний засіб слідчого є досить ефективним, бо спрямований безпосередньо на усунення наслідків кримінального правопорушення шляхом відновлення прав осіб, постраждалих від нього. Саме слідчий під час проведення розслідування кримінального правопорушення доказує характер і розмір, завданої потерпілому і цивільному позивачу шкоди.

Досить часто слідчі повертають потерпілим і цивільним позивачам майно, втрачене ними під час вчинення кримінальних правопорушень, а потім вилучене слідчим при проведенні обшуків у підозрюваного, обвинуваченого чи третіх осіб. Особливо багато правозахисних заходів виконують слідчі під час розслідування кримінальних правопорушень, вчинених неповнолітніми особами. Не менших правозахисних зусиль слідчого потребує забезпечення особистої недоторканності учасників досудового розслідування, які виконують у ньому допоміжну роль - свідків, понятих, спеціалістів, експертів та інших, а також їхнього достоїнства, доброго імені, особистої і сімейної таємниці тощо. Особливу увагу слідчий приділяє забезпеченню безпеки цим особам, в разі виникнення реальних загроз їхньому життю, здоров’ю чи майну. Тож взагалі досудове розслідування кримінальних правопорушень, що проводиться слідчим, за своїм характером i змістом є одним із різновидів загальнодержавної правозахисної діяльності, бо діючи як kontra, так і pro, слідчий не є владним суб'єктом, зацікавленим в результатах справи. Об'єктивний і неупереджений характер такого виду діяльності надає слідчому реальну можливість для постійної і успішної реалізації правозахисної (правозабезпечувальної) функції в різноманітних процесуальних формах.

Разом $з$ тим, нині діючі в Україні органи досудового розслідування мають багато суттєвих організаційних і процесуальних вад, над усуненням яких мають зосередити увагу як законодавець, так і теорія кримінального процесу. На них ми зупинятимося не будемо, бо це виходить за межі теми нашої публікації. Лише відзначимо, що наданий слідчому діючим КПК України комплекс правозахисних повноважень потребує суттєвого розширення. Сама ж його правозахисна (правозабезпечувальна) діяльність не повинна витікати із кримінальної процесуальної функції, що йменується досудовим розслідуванням кримінальних правопорушень (ст. 40 КПК України), а має бути закріплена законом в якості самостійної правозахисної (правозабезпечувальної) функції, чого вимагає ст. 3 Конституції України. Сутність, зміст і характер цієї функції слідчого також мають бути визначені на законодавчому рівні. 


\section{Мітература}

1. Скакун О.Ф. Теория государства и права (энциклопедический курс): учебник. Харьков: Эсиада, 2005. 840 с.

2. Рыжаков А.П. Предварительное расследование: учебное пособие. Тула, 1996. $320 \mathrm{c}$.

3. Парфёнова М.В. Охрана конституционных прав подозреваемого, обвиняемого в досудебных стадиях уголовного процесса. Москва: Юрлитинформ, 2004. 184 с.

4. Андрусяк В.Б. Додаткові функції слідчого. Вісник Харківського начіонального університету ім. В.Н. Каразіна: Серія «Право». 2009. Випуск 1 (5). № 841. С. 205-207.

5. Кавун Д.Ю. Захист прав жертви кримінального правопорушення у досудовому розслідуванні України. Юридична наука і практика: виклики сучасних євроінтеграційних процесів: матер. міжн. наук.-практ. конф м. Братислава, 27-28 листоп. 2015 р. C. $125-128$.

6. Куцова Э.Ф. Истина и состязательность в уголовном процессе. Учёные-юристы о современном праве / под ред. М.К. Треушникова. Москва: МГУ. 2005. Часть 3. C. $290-308$. 